\title{
SATU DASAWARSA KOLABORASI ILMIAH RISET KESEHATAN ZONA INDONESIA
}

\author{
Himawanto \\ Pascasarjana Ilmu Perpustakaan - Universitas Indonesia \\ Puslitbangtek Migas, LEMIGAS - Kementerian ESDM
}

Korespondensi: himawanto@ui.ac.id; himawanto@lemigas.esdm.go.id

Diajukan: 19 Juni 2017; Direview: 17 Juli 2017; Diterima: 28 Juli 2017; Direvisi: 25 September 2017

\begin{abstract}
Since health issues in Indonesia are seen as a common problem, scientific collaboration is growing and continuous. To examine collaboration indicators, study used bibliometric method based on research products published in ScienceDirect journal 2006-2015. The aims of this study are to detect level, index, sketch, and collaboration growth, including collaborators of national researchers. The results show that collaboration to overcome national health problems received high attention or $90 \%$ of the 146 generated research. Other collaboration levels exceeding limits of balance even though the research products, researchers, institutions, and countries often experience reduced growth. From number of research collaborations, Indonesia handles the largest number $(63,47.73 \%)$ and majority of them are multi-state. This best achievement is not separated on role of 40 national institutions and four of them highlighted the college and government. The geography is mostly located on the island of Java and the collaboration built in national institutions is also assisted by 28 countries. Collaborators are generally Asian and familiar to national institutions. National researchers should continue to raise health issues as cooperative baits with collaborators. So the goal to overcome the case and add international health publications can be realized.
\end{abstract}

\begin{abstract}
ABSTRAK
Sejak isu kesehatan di Indonesia dilihat sebagai problem bersama, kolaborasi ilmiah tumbuh dan berlangsung terus menerus. Untuk menelaah indikator kolaborasinya kajian ini memakai metode bibliometrik bersumber hasil riset yang dipublikasikan jurnal ScienceDirect tahun 2006-2015.Tujuannya untuk mendeteksi tingkat, indeks, sketsa, dan pertumbuhan kolaborasi termasuk kolaborator periset nasional. Hasil kajian menunjukkan kolaborasi untuk mengatasi persoalan kesehatan nasional mendapat atensi tinggi atau $90 \%$ dari 146 riset yang dihasilkan. Tingkat kolaborasi lainnya termasuk melebihi batas keseimbangan meskipun hasil riset, peneliti, institusi, dan negara tidak jarang mengalami penurunan pertumbuhan. Dari jumlah kolaborasi riset, Indonesia menangani jumlah terbesar $(63,47.73 \%)$ dan mayoritasnya berciri multipel negara. Prestasi terbaik ini tidak lepas atas peran 40 institusi nasional dan empat diantaranya ditonjolkan perguruan tinggi serta pemerintah. Adapun geografisnya banyak berlokasi di pulau Jawa dan kolaborasi yang terbangun di institusi nasional juga dibantu oleh 28 negara. Para kolaborator umumnya berasal dari Asia dan familiar di institusi nasional. Periset nasional sebaiknya terus mengangkat isu kesehatan sebagai umpan kerja sama dengan kolaborator. Sehingga tujuan untuk mengatasi perkara dan menambah publikasi internasional kesehatan bisa terealisasi.
\end{abstract}

Keywords: Research collaboration; Health research; Medical science; Bibliometrics; Indonesia

\section{PENDAHULUAN}

Persoalan kesehatan seakan tidak ada habisnya dan menjadi isu global diberbagai negara. Indonesia bahkan hingga kini masih fokus dalam mengatasi problem tersebut. Porsi dananya terus digelontorkan dan pertama kali di tahun 2016 terpenuhi 5\% dari total belanja negara. Namun dari alokasinya perlu ditelaah kembali berapa besaran yang diperuntukan bagi riset. Terkait kesehatan, Glassman et al (2013:40) pernah mengungkap nisbah kontribusi dana riset Indonesia 2007-2012 untuk vaksinasi global berada diposisi terakhir. Minimnya dana 
merupakan ancaman manakala periset ditarget secara kontinu memproduksi karya riset. Ditambah lagi tuntutan agar karya risetnya juga disebarluaskan ke publikasi ilmiah terpercaya. Periset akan dihadapkan beban yang banyak dan semestinya bermitra agar tak memikul sendiri. Kolaborasi riset kesehatan sudah banyak dilakukan dan berpeluang mengurangi beban periset. Meskipun demikian, tidak jarang para periset nasional belum mempertimbangkannya dan masih jauh dari keseimbangan (Handoyo et al, 2012:112).

Strata kolaborasi yang minim berpotensi menimbulkan kerawanan bagi pertumbuhan riset. Bahkan jika periset terus memilih cara individu, tidak mustahil terjadi kemerosotan pertumbuhan. Kendati cara individu masih saja ada, namun riset kesehatan telah banyak tercipta dari kolaborasi. Misalnya di topik radiografi, kolaborasinya sebesar 0.686 (Snaith, 2012:272). Riset penyakit jantung koroner dengan tingkat kolaborasi lebih dari 90\% (Yu et al, 2013:633). Bahkan riset HIV dan HPV, seluruh perisetnya absolut berkolaborasi (Vanni et al, 2014:3). Tetapi kolaborasi tidak hanya menuntut kecepatan, namun juga terciptanya hasil riset bermutu. Bagi pembaca, indikator mutu terlihat jika hasil-hasil riset kesehatan termuat di jurnal ilmiah, terutama yang terakreditasi. Bahkan semestinya jurnal juga terindeks di Scopus atau Thomson Reuters. Akan muncul kesangsian mutu jika hasil riset kesehatan tersalur ke jurnal berlabel meragukan, palsu, atau pemangsa.

Karya ilmiah di jurnal kesehatan akan tumbuh jika ide inovatif periset terkonstruksi secara ekspres. Jurnal adalah media yang selaras dengan hal di atas karena berfungsi sebagai komunikasi ilmiah utama dalam meningkatkan jumlah dan mutu hasil riset (Natakusumah, 2014:15; Maryono et al, 2012:15). Dunia sains mengenal, jurnal bermutu yang merangkum hasil-hasil riset kesehatan disediakan ScienceDirect. Eksistensinya terbilang populer karena mayoritas telah terindeks internasional. Semisal di institusi riset pertanian, pemanfaatannya lebih tinggi dari jurnal online lainnya (Rufaidah et al, 2012:22). ScienceDirect juga disediakan untuk memenuhi kebutuhan peneliti dan sivitas LIPI (Rahayu, 2013:30). Malahan sejak 20102012 terbanyak mengunduh jika dibandingkan 9 afiliasi lainnya yakni 115.504 artikel (Nashihuddin et al, 2013:6). Jika periset berstatus pemakai, semestinya mampu berperan juga menjadi produsen di terbitan ScienceDirect. Terutama berbekal mengangkat isu-isu kesehatan wilayahnya secara berkolaborasi.

Menurut pertimbangan di atas, hasil riset kesehatan yang digulirkan dengan kolaborasi dan mengangkat topik Indonesia akan di analisis pada kajian ini. Produk dimaksud yaitu artikel jurnal ScienceDirect yang di eksaminasi dengan metode bibliometrik. Sedangkan tujuannya adalah: (1) mendeteksi tingkat serta indeks kolaborasi, termasuk pertumbuhannya, (2) menginvestigasi sketsa kolaborasi, dan (3) menyelidiki kolaborator Indonesia sesuai zona bermukimnya. Dari kolaborasi jumlah karya riset berpeluang melonjak. Terlebih indikator mengukur kemajuan pengetahuan dan teknologi suatu bangsa adalah seberapa banyak karya dapat termuat dalam publikasi internasional (Surjandari et al, 2015:650). Oleh sebab itu kajian ini bermaslahat untuk menstimulan tercapainya kemajuan sains kesehatan bertaraf internasional bermodalkan isu-isu yang ada di Indonesia.

\section{TINJAUAN PUSTAKA}

Kolaborasi ilmiah berperan masif bagi kesinambungan ilmu pengetahuan di seluruh dunia. Praktiknya hingga kini di eksploitasi terus menerus karena banyak berimbas terhadap peningkatan jumlah tulisan ilmiah. Hal ini sejalan dengan motivasi utama para periset bahwa kolaborasi lebih diarahkan guna meningkatkan produktivitas riset (Youtie et al, 2014:958). Kolaborasi sendiri bisa didefinisikan sebagai proses berkembang dimana dua atau lebih entitas 
sosial, secara timbal balik aktif terlibat di kegiatan untuk meraih setidaknya satu tujuan bersama (Bedwell et al, 2012:130). Jenisnya adalah dalam atau luar sekolah, intra-disiplin ataupun interdisiplin, publik-swasta, serta domestik atau internasional (Abramo et al, 2013:444). Untuk mengidentifikasi jenis kolaborasi maka kepengarangan menjadi simpul utama yang dapat ditelaah dengan bibliometrik.

Bibliometrik sudah banyak mengungkap bukti manifestasi kolaborasi ilmiah di masa silam. Menurut Oxford English Dictionary yang dikutip kembali oleh Battisti et al (2012:353), Wilson (2012:121) dan Salini (2016:131), bibliometrik merupakan cabang dari ilmu perpustakaan yang menerapkan analisis matematika serta statistik bibliografi, buku, artikel, atau publikasi lainnya. Posisi pustakawan turut menentukan evolusi bibliometrik karena sejak periode 1990-an termasuk pemain kunci dan sudah menjadi bagian pada saat diskusinya dimulai (Roemer et al, 2015:30). Di periode yang sama pertumbuhan kolaborasi sendiri sudah mencapai kurang lebih 90\% dan sekitar 95-99\% artikel di jurnal prestise atau inti merupakan produk implementasinya (Beaver, 2013:48). Hingga kini di dunia publikasi, kolaborasi terus menjadi budaya pengkomunikasian ilmiah.

Format komunikasi ilmiah yang dipublikasikan adalah sumber potensial untuk pengukuran kolaborasi. Di kajian sebelumnya, pengungkapannya bisa melalui perhitungan tingkat dan indeks kolaborasi yang tersusun menurut level penulis, afiliasi, serta negara. Pada tema kesehatan, sejauh ini dua parameter yang mengungkap ketiga level tersaji di kajian Gazni et al (2012:326), Yu et al (2013:633), dan Su et al (2017:217). Sepertinya pengukuran demikian sudah menjadi kewajaran bila didestinasikan terhadap publikasi bertaraf internasional.

Sementara itu pengukuran kinerja para periset berkaitan erat dengan jumlah publikasi yang sudah dicapai. Produktivitasnya bisa berlainan dan biasa mengalami fluktuasi setiap tahun. Dalam mengukur pertumbuhan sains setiap periode maka publikasi menjadi sumber data paling relevan untuk di analisis (Bornmann et al, 2015:2216). Dari sejumlah studi di India, Maharana (2015:105) mendapati rata-rata pertumbuhan (AAGR) riset tuberkulosis 8.85\%. Lalu riset skizofrenia 21.80\% (Gupta et al, 2013:292), malaria 11.88\% (Maharana, 2014:55), dan migrain 17.37\% (Gupta et al, 2016:298). Sedangkan riset farmasi/farmakologi di Pakistan yaitu 29.29\% (Nasir et al, 2015:766), diabetes di Iran 25.5\% (Rasolabadi, 2015:160), dan glaukoma berskala dunia 6.94\% (Gupta et al, 2013:101). Fluktuasi pertumbuhan riset baik berciri mandiri atau kolaborasi tentu dapat dikaitkan dengan kemampuan para perisetnya dalam mengefisiensikan tempo perancangan karya ilmiah.

\section{METODE}

Kajian ini mendayagunakan bibliografi jurnal ilmiah yang tersedia di ScienceDirect dengan kurun waktu 2006-2015. Adapun sampelnya diambil pada Oktober 2016 melalui cara penelusuran sebagaimana Tabel 1. Melalui penelusuran, diperoleh 146 artikel yang kemudian dimigrasikan ke Ms-Excel 2010. Secara khusus software tersebut dipergunakan untuk tujuan analisis (Kolle et al, 2016:84; Wei et al, 2016:977; Hoppen et al, 2016:123; Guo et al, 2016:329; Li et al, 2017:2; Zhu et al, 2015:29). Demikian juga untuk perhitungan angka statistik, pemrosesan data, maupun grafik (Terekhov, 2017:1220; Chen et al, 2015:13). Kondisi ini memperlihatkan bahwa untuk keperluan studi bibliometrik, Ms-Excel telah menunjukkan bukti sebagai salah satu piranti lunak relevan. 
Tabel 1. Strategi Penelusuran di Pangkalan Data

\begin{tabular}{|c|c|c|}
\hline Kriteria Penelusuran & Fitur ScienceDirect & Kualifikasi \\
\hline Syarat Penelusuran & in Title & Indonesia \\
\hline Nominasi Jenis Publikasi & Journals & Jurnal Ilmiah \\
\hline Destinasi Subjek Kategori & $\begin{array}{l}\text { (1) Medicine and dentistry; (2) Nursing } \\
\text { and health professions; (3) Pharmacology, } \\
\text { toxicology and pharmaceutical science }\end{array}$ & $\begin{array}{l}\text { (1) Kedokteran dan kedokteran Gigi; (2) } \\
\text { Keperawatan dan profesi kesehatan; (3) } \\
\text { Farmakologi, toksikologi, dan ilmu farmasi }\end{array}$ \\
\hline Penetapan Jenis Dokumen & Article & Artikel \\
\hline
\end{tabular}

Pada studi bibliometrik ini tiga metode perhitungan dirujuk untuk pemeringkatan. Pertama, straight counting yang berbasis afiliasi penulis pertama dengan tanda karakter atau numerik awal. Sementara itu afiliasi nasional khususnya perguruan tinggi maupun negara kontributor dibakukan penamaannya sesuai identitas Indonesia. Untuk standardisasi perluasan geografis afiliasi menurut regional dirujuk kode area dari divisi statistik PBB (United Nations, 2011). Lalu pengukurannya bertumpu pada frekuensi kemunculan atau dengan norma full counting. Terkait ekspansi kawasan nasional merujuk pada data wilayah administrasi pemerintahan dalam negeri (Kemendagri, 2015). Sedangkan metode fractional counting sendiri dimanfaatkan untuk mengukur indeks kolaborasi. Ketiga metode perhitungan dimaksud secara umum difungsikan untuk penyusunan produktivitas dalam kegiatan kolaborasi ilmiah.

Kemudian unsur kepengarangan dijadikan fokus indikator kolaborasi. Mengacu pada jumlahnya, jenis kolaborasi bisa dideteksi baik dari peneliti, afiliasi, maupun negara. Afiliasi atau negara yang disebut berulang dalam satu artikel hasil penelitian, maka dihitung hanya sekali (Niu et al, 2014:1225). Sementara itu rumus yang dimanfaatkan untuk menganalisis kedua indikator kolaborasi, termasuk tingkat pertumbuhannya yaitu:

\section{A. Tingkat Kolaborasi}

(Yu et al, 2016:962; Zhang et al, 2016:299)

$$
\mathrm{DG}(\mathrm{Per})=\frac{\sum_{\mathrm{E}-\mathrm{I}}^{\mathrm{N}} \mathrm{Jp}}{\mathbb{N}}
$$

$$
D C(\operatorname{In} 8)=\frac{\sum_{d-1}^{A} J I}{\mathbb{N}}
$$

$$
\mathrm{DC}(\operatorname{Int})=\frac{\sum_{\mathrm{W}-1}^{\mathrm{A}} \mathrm{In}}{\mathrm{N}}
$$

\section{B. Indeks Kolaborasi}

(Rousseau, 2011:172; Liao et al, 2012:28)

$$
\mathrm{CI}=\frac{\sum_{\mathrm{N}=1}^{\mathrm{A}} \mathfrak{H}_{\mathrm{H}}}{\mathrm{H}}
$$

\section{Tingkat Pertumbuhan Kolaborasi}

(5) $\mathrm{GR}=\frac{\text { Endhg vahe }- \text { Starthg vahe }}{\text { Starteng vahue }} \times 100 \%$

\section{Dimana:}

$\mathrm{N} \quad$ Total artikel dalam periode kajian

Jp Jumlah artikel multipel-periset

Jl Jumlah artikel multipel-institusi

Jn Jumlah artikel multipel-negara

DC (Per) Kolaborasi periset

DC (Ins) Kolaborasi institusi

DC (Int) Kolaborasi internasional

CI Indeks kolaborasi

$\mathrm{f}_{\mathrm{j}} \quad$ Jumlah artikel dengan $\mathrm{j}$ " periset

GR Tingkat pertumbuhan kolaborasi

Untuk menjawab tujuan, komponen bibliografi yang telah diseleksi dilakukan analisis data. Adapun tahapannya: (1) menelaah jumlah kepengarangan serta pertumbuhannya, (2) mempelajari desain kolaborasi menurut institusi dan tempat bermukimnya, dan (3) menganalisis kemunculan kolaborator Indonesia berdasarkan lokasi geografisnya. Hasil analisis data adalah tabel dan grafik yang terproses dari pemeringkatan alfabet dari jumlah 
tertinggi hingga terkecil, serta tampilannya dilakukan penyederhanaan. Kemudian tabel dan grafik diinterpretasi secara deskriptif.

\section{HASIL DAN PEMBAHASAN}

Pengungkapan hasil mengenai kolaborasi riset bidang kesehatan yang terjadi di Indonesia tersusun dalam tiga ulasan. Ekspos tentang kekuatan dan pertumbuhan kolaborasi menjadi fokus pertama yang dilanjutkan dengan bahasan sketsa kepengarangannya. Terakhir adalah kolaborator yang berdampingan dengan peneliti Indonesia dalam melaksanakan riset kesehatan.

\subsection{Kekuatan dan Evolusi Kolaborasi}

Dengan berakhirnya satu dekade dari 2006-2015, diperoleh 146 produk riset kesehatan mengenai Indonesia. Dari perolehan tersebut, 132 produk adalah kinerja kolaborasi. Kajian ini memetakannya menurut tingkat dan indeks kolaborasi yang terbagi dalam skema peneliti, afiliasi maupun negara (Gambar 1). Tingkat kolaborasi ketiganya yakni masing-masing 90\%, 79\%, dan 60\%. Derajat kolaborasi pada level pertama cukup melebihi dari hasil kajian Singh (2016:304) sebesar 88.96\%. Demikian juga Sachithanantham et al (2015:573) senilai 81.82\% (405/495) dan Sangam et al (2016:16) sebesar $84.5 \%$. Sedangkan untuk tipe institusi, lebih unggul dibandingkan hasil studi $\mathrm{Su}$ et al (2017:217) yaitu 64\%. Melihat hal tersebut, riset kesehatan di Indonesia menciptakan animo para periset dan institusi untuk bermitra lebih intensif.

Terkait kolaborasi internasional (Gambar 1), melewati batas simetri dan mengungguli sejumlah riset sejenis. Semisal hasil kajian Huamani et al (2015:111), Snaith et al (2013:40), Cao et al (2013:711) dan Ahmed et al (2013:744) yang tingkat kolaborasinya di bawah 10\%. Sedangkan di atas 10\% hingga 35\% ditemukan pada kajian Hung et al (2012:260), Gupta et al (2016:304; 2014:435), Shahabuddin (2013:1619), Sweileh et al (2016:1), Lariviere et al (2013:1340), Ho et al (2016:638), dan Gul et al (2015:462). Tingkat kolaborasi internasional dapat saja bervariasi. Namun isu-isu kesehatan nasional ternyata lebih sukses mempengaruhi solidaritas sejumlah negara untuk menciptakan kolaborasi riset bertaraf internasional.

Sementara itu, ketiga indeks kolaborasi menurut Gambar 1 masing-masing senilai $5.79,2.75$, dan 1.90. Untuk periset dan afiliasi telah memperlihatkan rasio multipel. Dari sejumlah studi sebelumnya, indeks kolaborasi periset mampu melangkahi hasil yang diungkap Pinto et al (2013:1079) maupun Sing et al (2016:1180) yakni 2.62 dan 5 periset. Demikian halnya Santhanakarthikeyan et al (2014:22) senilai 5.47 dan Bouchard et al (2015:101) sebesar 3.92 periset. Lalu untuk kategori institusi, berdekatan dengan hasil kajian Wiles et al (2012:496) yakni 2.7. Melihat sejumlah kejadian sebelumnya, penanganan riset kesehatan di Indonesia dari 2006-2015 cenderung melahirkan kekuatan yang cukup menonjol, utamanya peneliti.

Sedangkan untuk level negara indeks kolaborasinya mengindikasikan pelibatan kurang dari dua. Namun demikian, angka tersebut cukup melampaui dari hasil penelitian Chen et al (2016:5) dengan indeks tertinggi 1.64. Demikian juga O'Leary et al (2015:314) sebesar 1.85 dan Su et al (2017:217) dengan indeks tertinggi 1.45. Penanganan persoalan saintifik yang melibatkan setidaknya dua negara sepertinya belum dipertimbangan oleh sebagian peneliti. Kendati hal demikian sudah menjadi penerapan lazim diberbagai cabang keilmuan. Namun melihat peristiwa yang terjadi di Indonesia, dapat dikatakan 
bahwa praktik pengentasan isu-isu kesehatan domestik mampu menciptakan komposisi bilateral lebih kuat.

Beralih ke Gambar 2 dan hasil memperlihatkan pertumbuhan kolaborasi berfluktuasi setiap tahunnya. Dalam kajian ini, empat indikator kolaborasi yakni produk, periset, afiliasi, dan negara dianalisis tingkat pertumbuhannya (GR). Produk kolaborasi mengalami situasi negatif selama empat tahun dengan rata-rata tingkat pertumbuhan $21.91 \%$ (197\%/9 tahun). Situasi yang sama terdapat di indikator negara, namun berbeda rasionya yakni $15.01 \%$. Lain halnya periset dan afiliasi, keduanya justru mengalami penurunan pertumbuhan dalam lima tahun. Sedangkan rata-rata pertumbuhannya berjumlah $11.74 \%$ dan $22.51 \%$. Dari keempat indikator kolaborasi di atas, terlihat mengalami gejala naik turun yang hampir seimbang.

Di kajian sebelumnya, keempat indikator di atas pernah diungkap pada kolaborasi riset internasional di Cina. Riset kesehatan termasuk didalammnya dan sejak 2002-2011, Niu et al (2014:1225) menemukan rerata pertumbuhannya masing-masing $16.73 \%$, $14.57 \%, 17.76 \%$, serta $16.96 \%$. Dari keempat indikator hanya rata-rata produk kolaborasi dan institusi riset yang mampu melampaui meskipun rentangnya kurang signifikan. Sepertinya kolaborasi riset kesehatan di Indonesia ataupun di negara luar, fenomena pertumbuhannya cukup serupa.

Fluktuasinya jumlah kolaborasi riset kesehatan pada tahun tertentu kemungkinan bisa dipengaruhi beban pekerjaan yang akan diselesaikan. Hal demikian terbilang beralasan dan bila merujuk pendapat Rahman et al (2017:277) maka setidaknya terdapat 14 kegiatan yang ditangani agar periset dapat mempublikasikan hasil risetnya. Besar kecilnya periset akan ada imbasnya terhadap waktu penyelesaian kegiatan. Sehingga kian besar formasi kolaborasinya, kegiatan riset kesehatan berpeluang cepat terselesaikan dan tumbuh dengan progresif.

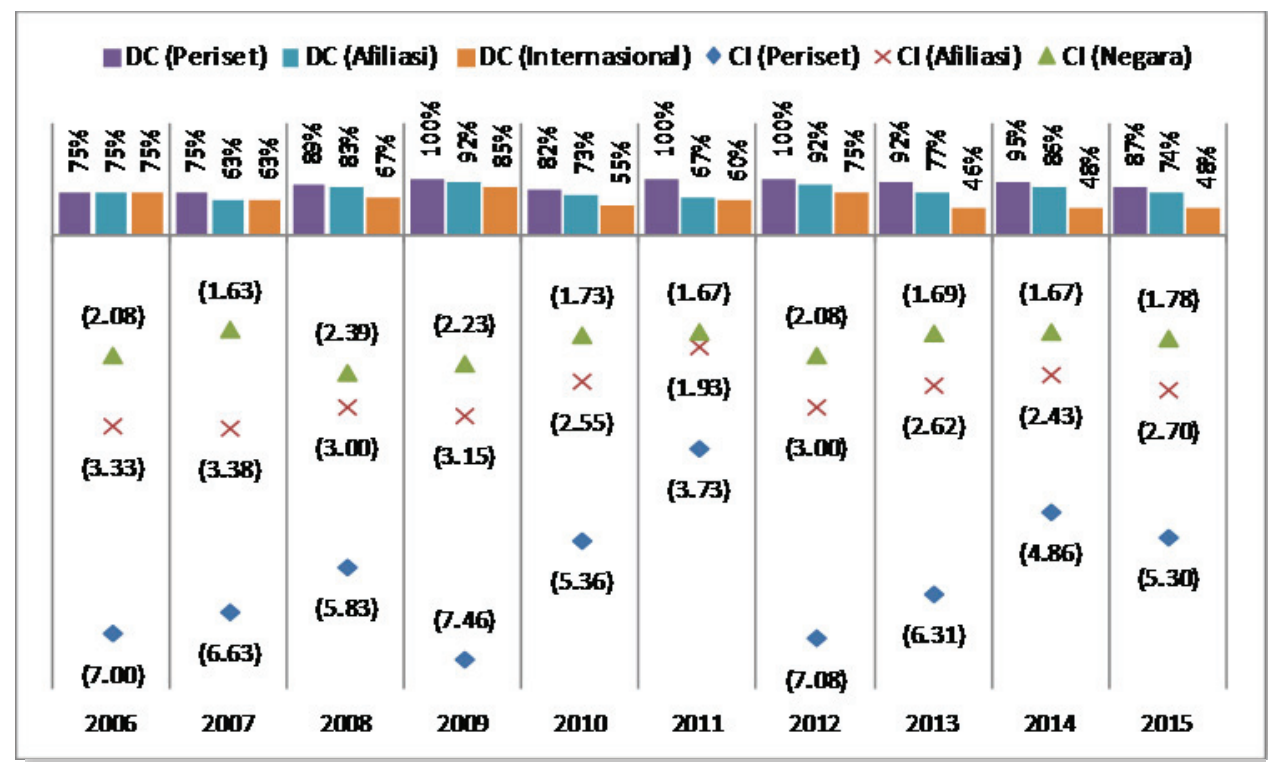

Gambar 1. Tingkat dan indeks kolaborasi penelitian kesehatan 


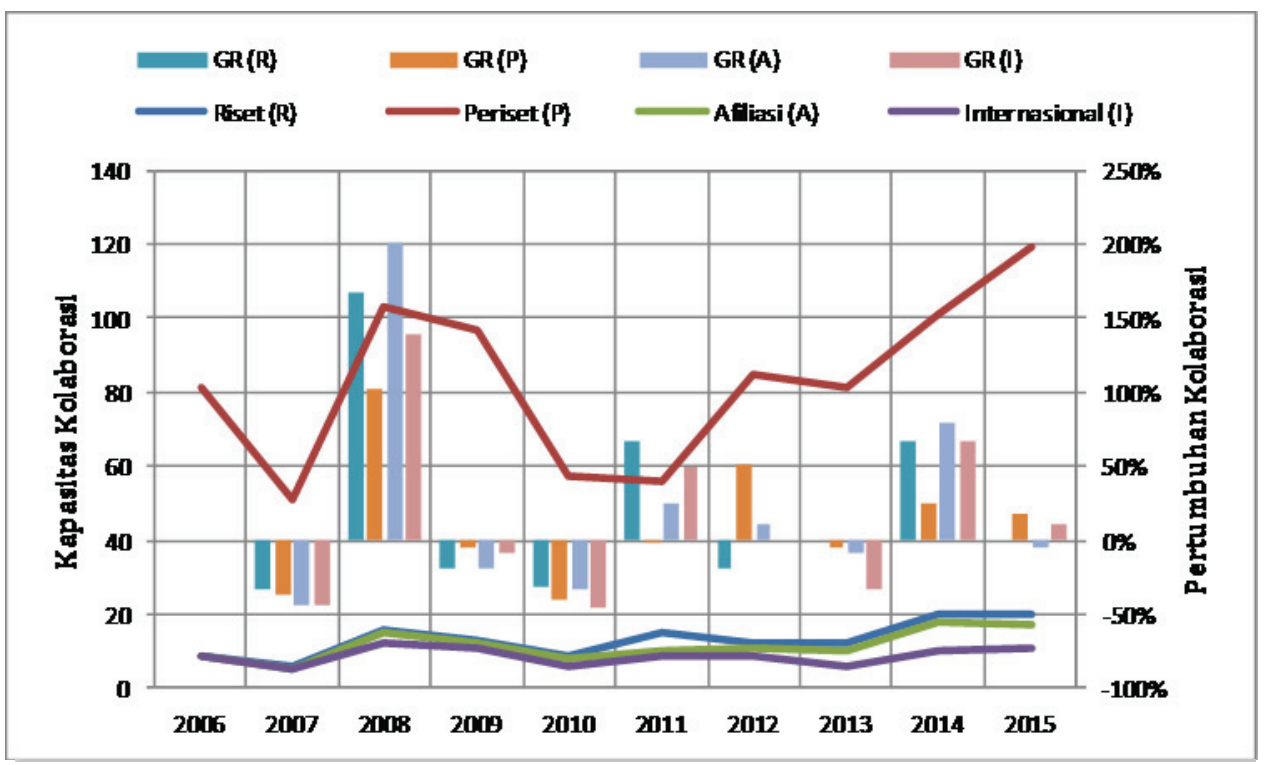

Gambar 2. Kolaborasi riset kesehatan dan pertumbuhannya

\subsection{Sketsa Kolaborasi Riset}

Sejak 2006-2015 dijumpai 20 negara yang menjalani kolaborasi riset untuk mengatasi isu-isu kesehatan nasional (Tabel 2). Indonesia memperlihatkan usaha maksimalnya dengan kinerja $47.73 \%$. Lalu menurut jumlah riset yang ditangani Indonesia, kolaborasi internasionalnya $61.19 \%$ dan terbilang signifikan karena melebihi batas keseimbangan. Mengorganisasikan kolaborasi yang mayoritasnya berskala global tidaklah mudah. Apalagi dari segi prestasi juga paling tinggi diantara negara lainnya. Sejauh ini pada topik kesehatan kondisi demikian jarang terjadi kecuali terdapat di Inggris dan Amerika Serikat (Sweileh et al, 2016:3;2017:7). Menyatukan misi dalam skala luas juga tidak simpel, terlebih guna menyaingi kinerja negara maju. Namun sebagai negara otonom terhadap isu-isu kesehatan, Indonesia wajar mengambil posisi esensial dalam mengatur kolaborasi riset dengan negara manapun.

Melihat kembali Tabel 2, kolaborasi internasional banyak tumbuh di negara maju. Sedangkan pada lingkup negara ASEAN, tidak seluruhnya berperan dalam kolaborasi internasional kecuali Malaysia, Filipina, dan Singapura. Sepertinya solidaritas ASEAN untuk bersama-sama mengentaskan permasalahan kesehatan di Indonesia belum banyak terealisasi. Aksi kebersamaannya malahan pernah terwujud dengan negara-negara di Uni Eropa. Bahkan jumlah kolaborasinya menempati posisi pertama dari tujuh bidang riset lainnya hingga 41\% (Hassan et al, 2012:1040). Kajian ini menggarisbawahi, aksi kekompakan ASEAN termasuk langkah awal terbaik untuk dapat menyaingi prestasi negara-negara maju, khususnya dalam meningkatkan kapasitas publikasi internasional. Melihat hal tersebut, Indonesia sebisa mungkin mengorganisasikan komunitas ilmiah lebih baik, tangguh dan berkelanjutan.

Sementara itu Tabel 3 memperlihatkan institusi yang berperan utama dalam kolaborasi riset kesehatan di Indonesia. Dari 97 lembaga penelitian, keterwakilan Indonesia berjumlah $41.24 \%$ (40/97) dan sisanya berasal dari mitra sahabat. Universitas Indonesia (UI) mendapati angka tertinggi dengan hasil 6.82\%. Sedangkan diurutan kedua terdapat institusi pemerintah dan dua perguruan tinggi asal Indonesia dengan perolehan prestasi yaitu 3.03\%. Kapasitas kolaborasi internasional yang ditangani UI sendiri yakni 
$44.44 \%$, berbeda dengan perguruan tinggi nasional peringkat kedua dengan kinerja absolut. Sebelumnya Lakitan et al (2012:235) mengungkap bahwa UI termasuk institusi produktif yang berpengalaman dalam memimpin kolaborasi riset sejak 2001-2011, termasuk dengan mitra asing. Kebolehan dalam mengelola riset global sebaiknya terus ditonjolkan kepada negara lain. Sehingga UI atau institusi lokal kapabel lainnya mendapat legitimasi menangani isu-isu kesehatan di negara sahabat.

Kemudian hasil Gambar 3 menampilkan provinsi nasional yang mengetuai kolaborasi riset kesehatan di Indonesia. Dari hasil yang diperoleh periset nasional, kajian ini mendapati 13 provinsi pengendali kolaborasi, baik nasional maupun internasional. Melihat jumlahnya, belum banyak daerah berpartisipasi dalam kolaborasi riset kesehatan karena belum setengah dari provinsi yang ada. DKI Jakarta, Jawa Barat, Jawa Timur merupakan tiga provinsi paling banyak menangani kolaborasi yaitu masing-masing $38.10 \%, 20.63 \%$, dan $9.52 \%$. Ketiganya termasuk provinsi yang berlokasi di pulau Jawa dan dapat dikatakan sebagai wilayah kreatif, karena membukukan kinerja setengah lebih dari jumlah kolaborasi riset milik Indonesia.

Berkaitan kondisi di atas, afiliasi lokal yang bermukim di luar pulau Jawa semestinya bisa berperforma aktif di kolaborasi. Mulyanto (2016:88) pernah menyatakan jika institusi riset di pulau Jawa memang lebih produktif jika dibandingkan wilayah lain. Produktivitas ini timbul akibat peranan sektor pendidikan seperti perguruan tinggi atau universitas yang sering berprestasi di ajang publikasi internasional. Jika pulau Jawa meraih posisi teratas tentu tidak mengherankan. Mengingat populasi afiliasi pendidikan tinggi di Jawa lebih besar jumlahnya daripada pulau lain (Moeliodihardjo et al, 2012:309). Namun berbekal pengalaman saat mengetuai kolaborasi riset internasional, afiliasi lokal yang ada di Sumatera, Nusa Tenggara, ataupun Sulawesi berpeluang dapat menaikan prestasinya. Terutama dengan bermodal isu-isu kesehatan di wilayahnya dan merekrut mitra asing untuk berkolaborasi.

Tabel 2. Sketsa Kolaborasi Riset Kesehatan Menurut Zona Negara

\begin{tabular}{|c|c|c|c|c|c|c|}
\hline Negara Kontributor & Produk Kolaborasi (PK) & $\%(\mathrm{PK})$ & (PK) Nasional & $\%$ dari TR & (PK) Internasional & $\%$ dari TR \\
\hline Indonesia & 63 & 47.73 & 22 & 32.84 & 41 & 61.19 \\
\hline Amerika Serikat & 16 & 12.12 & 6 & 27.27 & 10 & 45.45 \\
\hline Australia & 11 & 8.33 & 7 & 63.64 & 4 & 36.36 \\
\hline Jepang & 8 & 6.06 & 3 & 37.50 & 5 & 62.50 \\
\hline Inggris & 7 & 5.30 & 2 & 25.00 & 5 & 62.50 \\
\hline Belanda & 6 & 4.55 & 1 & 14.29 & 5 & 71.43 \\
\hline Jerman & 3 & 2.27 & 1 & 33.33 & 2 & 66.67 \\
\hline Perancis & 3 & 2.27 & 0 & 0.00 & 3 & 100 \\
\hline Malaysia & 2 & 1.52 & 1 & 50.00 & 1 & 50.00 \\
\hline Swiss & 2 & 1.52 & 1 & 50.00 & 1 & 50.00 \\
\hline Swedia & 2 & 1.52 & 0 & 0.00 & 2 & 100 \\
\hline (Lainnya) $9 \mathrm{Negara}$ & 9 & 6.82 & 0 & 0.00 & 9 & 81.82 \\
\hline
\end{tabular}


Tabel 3. Sebaran Kolaborasi Studi Kesehatan Berdasarkan Institusi

\begin{tabular}{|c|c|c|c|c|c|c|}
\hline Organisasi Penelitian & Total $(\mathrm{K})$ & $\%(\mathrm{~K})$ & (K) Nasional & $\%$ dari TR & (K) Internasional & $\%$ dari TR \\
\hline Universitas Indonesia & 9 & 6.82 & 5 & 55.56 & 4 & 44.44 \\
\hline Direktorat Jenderal P3L & 4 & 3.03 & 1 & 25.00 & 3 & 75.00 \\
\hline Johns Hopkins School of Medicine & 4 & 3.03 & 0 & 0.00 & 4 & 100 \\
\hline Universitas Airlangga & 4 & 3.03 & 0 & 0.00 & 4 & 100 \\
\hline Universitas Syiah Kuala & 4 & 3.03 & 0 & 0.00 & 4 & 100 \\
\hline University of Melbourne & 3 & 2.27 & 3 & 100 & 0 & 0.00 \\
\hline Universitas Gadjah Mada & 3 & 2.27 & 0 & 0.00 & 3 & 100 \\
\hline Balitkabi & 2 & 1.52 & 2 & 100 & 0 & 0.00 \\
\hline Universitas Pancasila & 2 & 1.52 & 2 & 100 & 0 & 0.00 \\
\hline Australian National University & 2 & 1.52 & 1 & 50.00 & 1 & 50.00 \\
\hline Institut Pertanian Bogor & 2 & 1.52 & 1 & 50.00 & 1 & 50.00 \\
\hline Yale University & 2 & 1.52 & 1 & 33.33 & 1 & 33.33 \\
\hline Badan Litbang Kesehatan & 2 & 1.52 & 0 & 0.00 & 2 & 100 \\
\hline Kobe University & 2 & 1.52 & 0 & 0.00 & 2 & 100 \\
\hline Menzies School of Health Research & 2 & 1.52 & 0 & 0.00 & 2 & 100 \\
\hline University of Aberdeen & 2 & 1.52 & 0 & 0.00 & 2 & 100 \\
\hline University of Illinois at Chicago & 2 & 1.52 & 0 & 0.00 & 2 & 100 \\
\hline University of Tokyo & 2 & 1.52 & 0 & 0.00 & 2 & 100 \\
\hline (Lainnya) 79 Organisasi Penelitian & 79 & 59.85 & 28 & 30.43 & 51 & 55.43 \\
\hline
\end{tabular}

Sumber: Data primer yang diolah, 2016. TR (Total produk riset masing-masing organisasi); K (Kolaborasi)

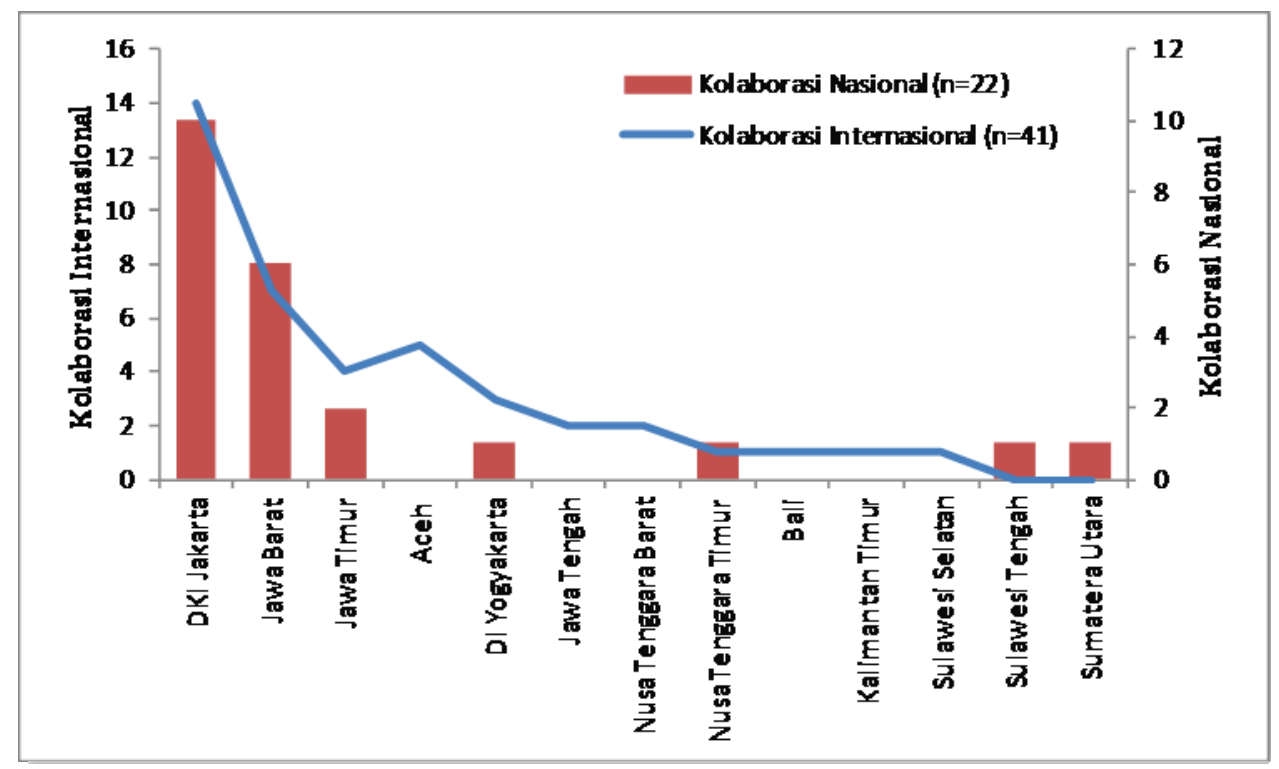

Gambar 3. Porsi kolaborasi propinsi domestik di riset kesehatan

\subsection{Kolaborator Penelitian Indonesia}

Untuk menyelesaikan problem kesehatan nasional, Indonesia turut bermitra dengan 28 negara sahabat. Jumlah ini berdasarkan kolaborasi internasional yang mencantumkan afiliasi Indonesia, baik sebagai penulis utama ataupun pendukung. Gambar 4 menunjukkan dari 272 kemunculan, Jepang merupakan kolaborator Indonesia teraktif dengan nilai 20\%. Diikuti berikutnya oleh Amerika Serikat dan Belanda, masing-masing $15 \%$ serta $14 \%$. Melihat fakta sebelumnya untuk menangani 110 kolaborasi riset kesehatan periode 1980-2012, Indonesia juga memperoleh jumlah yang sama dengan berkoalisi 28 negara (Hossain et al, 2015:349). Hadirnya kolaborator baru bisa saja terealisasi jika periset nasional berkomunikasi intensif, misalnya dengan negara tetangga atau yang tergabung dalam komunitas ilmiah global. 
Sementara itu negara-negara dengan kemunculan dua persen lebih adalah mitra yang umumnya tidak asing bagi institusi nasional (Gambar 4). Peranan mitra tersebut tidak hanya berhubungan dengan riset kesehatan semata. Melainkan juga seluruh bidang riset yang ada dan diselenggarakan oleh 50 institusi Indonesia (Lukman et al, 2016:20). Menariknya posisi Indonesia termasuk diminati negara lain sebagai kolaborator utama. Misalnya Malaysia yang mencantumkan Indonesia dalam sepuluh besar (Cheng et al, 2013:665). Kemudian Australia yang juga sering berkolaborasi dengan periset nasional (Minas et al, 2014:6). Bahkan dalam lingkup Asia, Indonesia termasuk kolaborator negara-negara Arab yang berada di posisi tiga besar (Sweileh et al, 2014:6). Kondisi di atas membuktikan bahwa posisi Indonesia terbilang strategis dalam mendukung riset kesehatan bertaraf internasional bagi banyak negara.

Terkait hasil Gambar 5, diperoleh sebelas regional setelah dipetakan geografis negara kolaborator. Terlihat wilayah para kolaborator mayoritas terdapat di Asia Timur (27.9\%). Diikuti Eropa Barat 21.7\% dan Amerika Utara 15.4\%. Secara umum benua Asia, Eropa, dan Amerika merupakan wilayah bermukimnya kolaborator Indonesia. Posisi Asia di kolaborasi internasional hingga sekarang memang pantas diperhitungkan. Prestasinya yang terekam di sejumlah kajian bibliometrik kesehatan umumnya berdekatan dengan sang juara Eropa (Yao et al, 2014:759; Ramos et al, 2013:6; Huai et al, 2016:1540; Sweileh et al, 2016:3). Nampaknya Asia berpeluang kuat menjadi unsur penyeimbang Eropa dan Indonesia dapat berbuat andil didalamnya. Untuk itu periset Indonesia sebaik mungkin menjadikan isu-isu kesehatan sebagai modal kolaborasi. Tujuannya antara lain untuk menaikan jumlah publikasi internasional sekaligus menyelesaikan problem kesehatan negaranya.

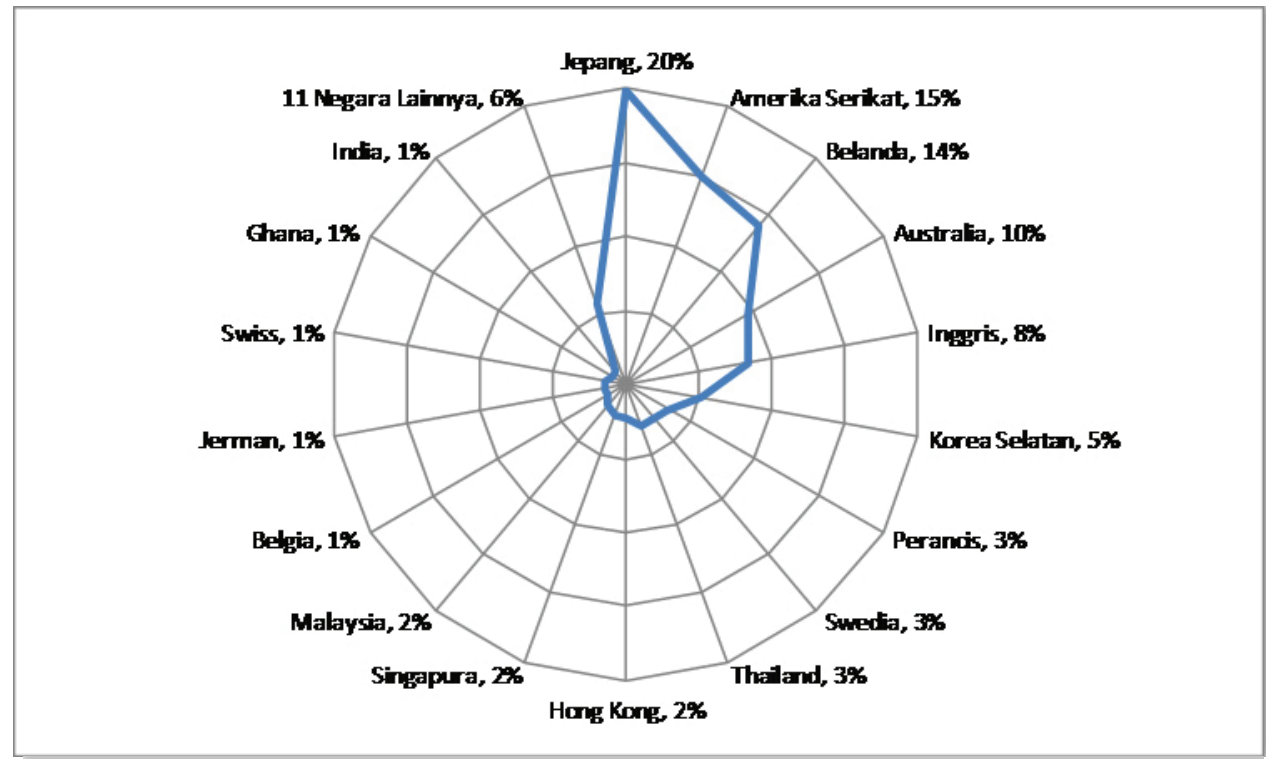

Gambar 4. Tingkat kemunculan kolaborator Indonesia pada studi kesehatan 


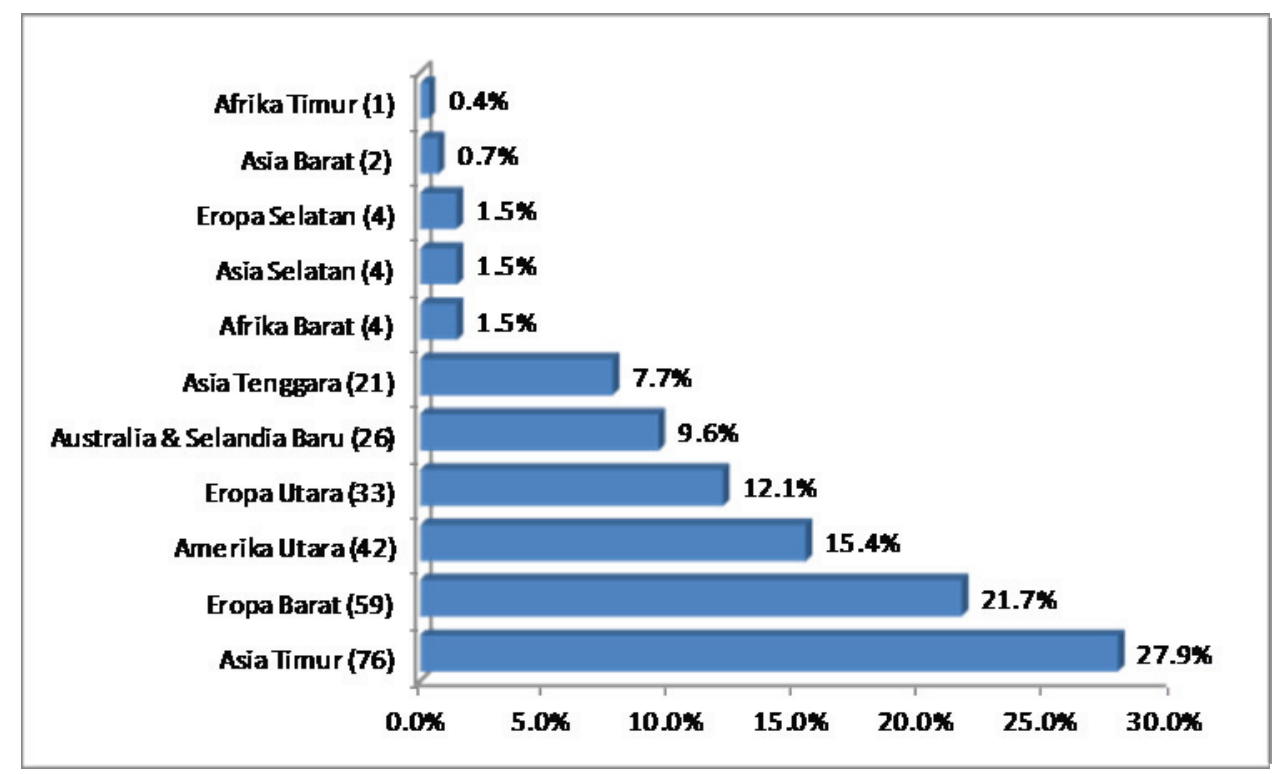

Gambar 5. Sekutu Indonesia di riset kesehatan menurut kawasan regional

\section{KESIMPULAN}

Sejak dasawarsa terakhir (2006-2015) kerja sama untuk mengatasi persoalan kesehatan di Indonesia telah banyak dilakukan. Peristiwa tersebut terekam dalam publikasi ScienceDirect yang menampilkan sebagian besar atau 90\% dari 146 produk riset adalah hasil kolaborasi. Menariknya tingkat kolaborasi lainnya berhasil melewati batas keseimbangan. Padahal dalam beberapa tahun sejumlah indikatornya mulai dari hasil riset, peneliti, institusi, dan negara tidak jarang mengalami penurunan pertumbuhan. Dari riset yang dikoalisikan, Indonesia menangani jumlah terbesar $(63,47.73 \%)$ dan mayoritasnya adalah kolaborasi internasional. Prestasi terbaik Indonesia ini tidak lepas atas peran 40 institusi nasional dan empat diantaranya yang menonjol berasal dari perguruan tinggi serta pemerintah. Umumnya institusi nasional berlokasi di pulau Jawa seperti DKI Jakarta, Jawa Barat, dan Jawa Timur. Adapun kolaborasi yang terbangun di institusi lokal juga didukung oleh 28 negara. Namanama kolaborator kebanyakan terdapat di Asia dan familiar di komunitas lembaga riset nasional. Untuk itu periset nasional sebaik mungkin terus mengangkat isu kesehatan sebagai umpan kerja sama dengan negara-negara di Asia. Dengan demikian misi untuk mengatasi permasalahan dan menambah jumlah publikasi internasional kesehatan bisa terealisasi.

\section{DAFTAR PUSTAKA}

Abramo, Giovanni et al. 2013. The Collaboration Behaviors of Scientists in Italy: a Field Level Analysis. Journal of Informetrics, Vol.7, No.2: 442-454. DOI:10.1016/j.joi.2013.01.009.

Ahmed, K.K. Mueen et al. 2013. India's Contribution on Antioxidants: a Bibliometric Analysis, 200110. Scientometrics, Vol.94, No.2: 741-754. DOI:10.1007/s11192-012-0700-2.

Battisti, Francesca De et al. 2012. Bibliographic Data: a Different Analysis Perspective. Electronic Journal of Applied Statistical Analysis, Vol.5, No.3: 353-359. DOI:10.1285/i20705948v5n3p353.

Beaver, Donald deB. 2013. The Many Faces of Collaboration and Teamwork in Scientific Research: Updated Reflections on Scientific Collaboration. COLLNET Journal of Scientometrics and Information Management, Vol.7, No.1: 45-54. DOI:10.1080/09737766.2013.802629. 
Bedwell, Wendy L. et al. 2012. Collaboration at Work: an Integrative Multilevel Conceptualization. Human Resource Management Review, Vol.22, No.2: 128-145. DOI:10.1016/j.hrmr.2011.11.007.

Bornmann, Lutz et al. 2015. Growth Rates of Modern Science: a Bibliometric Analysis Based on The Number of Publications and Cited References. Journal of the Association for Information Science and Technology, Vol.66, No.11: 2215-2222. DOI:10.1002/asi.23329.

Bouchard, Louise et al. 2015. Research on Health Inequalities: a Bibliometric Analysis (1966-2014). Social Science \& Medicine, Vol.141, September: 100-108. DOI:10.1016/j.socscimed.2015.07.022.

Cao, Yang et al. 2013. A Bibliometric Analysis of Global Laparoscopy Research Trends During 19972011. Scientometrics, Vol.96, No.3: 717-730. DOI:10.1007/s11192-012-0942-z

Chen, Huaqi et al. 2015. Highly Cited Articles in Biomass Research: a Bibliometric Analysis. Renewable and Sustainable Energy Reviews, Vol.49, September: 12-20. DOI:10.1016/j.rser.2015.04.060.

Chen, Kai et al. 2016. International Publication Trends and Collaboration Performance of China in Healthcare Science and Services Research. Israel Journal of Health Policy Research, Vol.5, No.1: 1-15. DOI:10.1186/s13584-016-0061-z.

Cheng, Ming et al. 2013. Patterns of Co-Authorship and Research Collaboration in Malaysia. Aslib Proceedings: New Information Perspectives, Vol.65, No.6: 659-674. DOI:10.1108/AP-12-20120094.

Gazni, Ali et al. 2012. Mapping World Scientific Collaboration: Authors, Institutions, and Countries. Journal of the Association for Information Science and Technology, Vol.63, No.2: 323-335. DOI: 10.1002/asi.21688.

Glassman, Amanda et al. 2013. Measuring Government Commitment to Vaccination. Vaccine, Vol. 31, No.Supplement 2: 32-42. DOI:10.1016/j.vaccine.2012.12.036.

Gul, Summer et al. 2015. Research Output on Lavender, 2008-2012. European Journal of Integrative Medicine, Vol.7, No.5: 460-466. DOI:10.1016/j.eujim.2015.05.004.

Guo, Lin et al. 2016. A Bibliometric Analysis of Oyster Research from 1991 to 2014. Aquaculture International, Vol.24, No.1: 327-344. DOI:10.1007/s10499-015-992.

Gupta, B.M. et al. 2013. A Scientometrics Approach to Schizophrenia Research in India: an analysis of Publications Output During 2002-11. Asian Journal of Psychiatry, Vol.6, No.4: 292-298. DOI:10.1016/j.ajp.2013.01.007.

Gupta, B.M. et al. 2013. World Glaucoma Research: a Quantitative Analysis of Research Output During 2002-11. Annals of Library and Information Studies, vol.60, no.2: 98-106. http://op.niscair.res.in/index.php/ALIS/article/view/300.

Gupta, Ritu. 2016. Scientometric Assessment of India's Migraine Research Publications During 200615. Journal of Young Pharmacists, Vol.8, No.4: 294-301. DOI:10.5530/jyp.2016.4.2.

Gupta, Ritu. 2016. A Scientometric Assessment of Indian Publications on Vitamin D Deficiency During 2006-15. Journal of Young Pharmacists, Vol.8, No.4: 302-309. DOI:10.5530/jyp.2016.4.3.

Gupta, Ritu et al. 2014. Indian Lymphoma Research: a Scientometric Analysis of Indian Publications Output During 2004-2013. COLLNET Journal of Scientometrics and Information Management, Vol.8, No.2: 419-436. DOI:10.1080/09737766.2014.954866. 
Handoyo, Setiowiji et al. 2012. Tingkat Kolaborasi Peneliti pada Program Insentif "Semi Top-Down" Kementerian Riset dan Teknologi, Tahun 2008-2010. Warta KIML, Vol.10, No.2: 99-114. DOI:10.14203/STIPM.2012.3.

Hassan, Saeed-Ul et al. 2012. A Bibliometric Study of Research Activity in ASEAN related to the EU in FP7 Priority Areas. Scientometrics, Vol.91, No.3: 1035-1051. DOI:10.1007/s11192-012-06651 .

Ho, Yuh-Shan et al. 2016. A bibliometric analysis of dengue-related publications in the Science Citation Index Expanded. Future Virology, Vol.11, No.9: 631-648. DOI:10.2217/fvl-2016-0057.

Hoppen, Natascha Helena Franz et al. 2016. Neurosciences in Brazil: a Bibliometric Study of Main Characteristics, Collaboration, and Citations. Scientometrics, Vol.109, No.1: 121-141. DOI: 10.1007/s11192-016-1919-0.

Hossain, Liaquat et al. 2015. Evolutionary Longitudinal Network Dynamics of Global Zoonotic Research. Scientometrics, Vol.103, No.2: 337-353. DOI:10.1007/s11192-015-1557-y.

Huai, Cuiqian et al. 2016. A Bibliometric Analysis on The Performance and Underlying Dynamic Patterns of Water Security Research. Scientometrics, Vol.108, No.3: 1531-1551. DOI:10.1007/s11192-016-2019-x.

Huamani, Charles et al. 2015. Scientific Research in Obstructive Sleep Apnea Syndrome: Bibliometric Analysis in SCOPUS, 1991-2012. Sleep and Breathing, Vol.19, No.1: 109-114. DOI:10.1007/s11325-014-0969-x.

Hung, Kuang-Chen et al. 2012. Global Trend in Articles Related to Stereotactic Published in Science Citation Index-Expanded. British Journal of Neurosurgery, Vol.26, No.2: 258-264. DOI:10.3109/02688697. 2011.626876.

Kementerian Dalam Negeri. 2015. Kode dan Data Wilayah Administrasi Pemerintahan. Peraturan Menteri Dalam Negeri Nomor 56 Tahun 2015. Jakarta, 29 Juni.

Kolle, Shankar Reddy et al. 2016. Global Research on Air Pollution Between 2005 and 2014: a Bibliometric Study. Collection Building, Vol.35, No.3: 84-92. DOI:10.1108/CB-05-2016-0008.

Lakitan, Benyamin et al. 2012. Scientific Productivity and The Collaboration Intensity of Indonesian Universities and Public R\&D Institutions: Are There Dependencies on Collaborative R\&D with Foreign Institutions?. Technology in Society, Vol.34, No:3: 227-238. DOI:10.1016/j.techsoc.2012.06.001.

Lariviere, Vincent et al. 2013. International Comparative Performance of Mental Health Research 19802011. European Neuropsychopharmacology, Vol.23, No.11: 1340-1347. DOI:10.1016/j.euroneuro.2013.01.006.

Li, Lin et al. 2017. A Bibliometric and Visual Analysis of Global Geo-Ontology Research. Computers \& Geosciences, Vol.99, No. February: 1-8. DOI:10.1016/j.cageo.2016.10.006.

Liao, Chien Hsiang et al. 2012. Quantifying the Degree of Research Collaboration: a Comparative Study of Collaborative Measures. Journal of Informetrics, Vol. 6, No.1: 27-33. DOI:10.1016/j.joi.2011.09.003.

Lukman et al. 2016. Kekuatan 50 institusi ilmiah Indonesia: Profil publikasi ilmiah terindeks Scopus. Jakarta: Kementerian Riset, Teknologi, dan Pendidikan Tinggi. http://risbang.ristekdikti.go.id

Maharana, Rabindra K. 2014. Malaria Research in India during 2003-2012: a Bibliometric Analysis. Collection Building, Vol.33, No.2: 53-59. DOI:10.1108/CB-01-2014-0004. 
Maharana, Rabindra K. 2015. Mapping of Tuberculosis (TB) Research in India during 2004-2013: a Bibliometric Analysis. Collection Building, Vol.34, No.3: 102-111. DOI:10.1108/CB-10-20140048 .

Maryono et al. 2012. Indonesian Journal of Chemistry 2007-2011: Analisis Kolaborasi dan Institusi. Visi Pustaka, Vol.14, No.3: 13-23.

Minas, Harry et al. 2014. International Journal of Mental Health Systems: A Bibliometric Study. International Journal of Mental Health Systems, Vol.8, No.1: 1-10. DOI:10.1186/1752-4458-8-1.

Moeliodihardjo, Bagyo Y et al. 2012. University, Industry, and Government Partnership: Its Present and Future Challenges in Indonesia. Procedia - Social and Behavioral Sciences, Vol.52 : 307-316. DOI:10.1016/j.sbspro.2012.09.468.

Mulyanto. 2016. Productivity of R\&D Institution: The case of Indonesia. Technology in Society, Vol.44, No. February: 78-91. DOI:10.1016/j.techsoc.2015.12.001.

Nashihuddin, Wahid et al. 2013. Aksesibilitas Informasi Ilmiah ScienceDirect Pustaka Ristek di Lingkungan Ristek dan LPNK. Jurnal Pustakawan Indonesia, Vol.12, No.2: 1-9.

Nasir, Saima et al. 2015. A Bibliometric Analysis of Pharmacy/Pharmacology Research in Pakistan. International Journal of Pharmacology, Vol.11, No.7: 766-772. DOI:10.3923/ijp.2015.766.772.

Natakusumah, Engkos Koswara. 2014. Penentuan Kolaborasi Penelitian dan Distribusi Pengarang pada Jurnal Teknologi Indonesia. BACA: Jurnal Dokumentasi dan Informasi, Vol.35, No.1: 15-24.

Niu, Fenggao et al. 2014. Network Structure, Distribution and The Growth of Chinese International Research Collaboration. Scientometrics, Vol.98,No.2: 1221-1233. DOI:10.1007/s11192-013$1170-\mathrm{x}$

O'Leary, James D et al. 2015. Benchmarking Bibliometrics in Biomedical Research: Research Performance of the University of Toronto's Faculty of Medicine, 2008-2012. Scientometrics, Vol.105, No.1: 311-321. DOI:10.1007/s11192-015-1676-5.

Pinto, Maria et al. 2013. Information Literacy in Social Sciences and Health Sciences: a Bibliometric Study (1974-2011). Scientometrics, Vol.95, No.3: 1071-1094. DOI:10.1007/s11192-012-0899-y

Rahayu, Rochani Nani. 2013. Profil Pusat Dokumentasi dan Informasi Ilmiah. Jurnal Pustakawan Indonesia, Vol.12, No.1: 29-31.

Rahman, Mohammad Tariqur et al. 2017. The Need to Quantify Authors' Relative Intellectual Contributions in a Multi-Author Paper. Journal of Informetrics, Vol.11, No.1: 275-281. DOI:10.1016/j.joi.2017.01.002.

Ramos, Jose M. et al. 2013. Bibliometric Analysis of Leishmaniasis Research in Medline (1945-2010). Parasites \& Vectors, Vol.6, No.1: 1-14: DOI:10.1186/1756-3305-6-55.

Rasolabadi, Masoud et al. 2016. Diabetes Research in Iran: a Scientometric Analysis of Publications Output. Acta Informatica Medica, Vol.23, No.3: 160-164. DOI:10.5455/aim.2015.23.160-164.

Roemer, Robin Chin et al. 2015. Understanding bibliometrics. In Meaningful metrics: a 21 st Century Librarian's Guide to Bibliometrics, Altmetrics, and Research Impact (pp. 27-69). Association of College and Research Libraries.

Rousseau, Ronald. 2011. Comments on The Modified Collaborative Coefficient. Scientometrics, Vol.87, No.1: 171-174. DOI:10.1007/s11192-010-0300-y. 
Rufaidah, Vivit Wardah et al. 2012. Akses Pemustaka ke Jurnal Online di Pusat Perpustakaan dan Penyebaran Teknologi Pertanian. Jurnal Perpustakaan Pertanian, Vol.21, No.1: 15-22.

Sachithanantham, Shanmugam et al. 2015. Scientometric Analysis of Rabies Research Literature in India: 1950-2014. Scientometrics, Vol.105, No.1: 567-575. DOI:10.1007/s11192-015-1694-3

Salini, Silvia. 2016. An Introduction To Bibliometrics. In Greenfield, Tony et al. (Eds.), Research Methods for Postgraduates. Third Edition (pp. 130-143). Wiley. DOI:10.1002/9781118763025.ch14.

Sangam, S.L. et al. 2016. Growth Versus Scientific Collaboration in The Field of Genetics: A Scientometrics Analysis. COLLNET Journal of Scientometrics and Information Management, Vol.10, No.1: 9-19. DOI:10.1080/09737766.2016.1177938.

Santhanakarthikeyan, S. et al. 2014. Research Publications to Indian Journal of Cancer: a Scientometric Analysis. Library Hi Tech News, Vol.31, No.3: 21-25. DOI:10.1108/LHTN-11-2013-0068.

Shahabuddin, Sheikh Mohammed. 2013. Mapping Neuroscience Research in India - a Bibliometric Approach. Current Science, Vol.104, No.12: 1619-1626.

Singh, Nirmal. 2016. Scientometric Analysis Of Research on Zika virus. Virus Disease, Vol.27, No.3: 303-306. DOI:10.1007/s13337-016-0339-3.

Singh, Nirmal et al. 2016. Mapping of Breast Cancer Research in India: a Bibliometric Analysis.Current Science, Vol.110, No.7: 1178-1183.

Snaith, Beverly. 2012. Collaboration in Radiography: a Bibliometric Analysis. Radiography, Vol.18, No.4: 270-274. DOI:10.1016/j.radi.2012.07.003

Snaith, Beverly A. 2013. Peer-Review Publication Patterns: a Comparison of International Radiography Journals. Journal of Medical Imaging and Radiation Sciences, Vol.44, No.1: 37-43. DOI:10.1016/j.jmir.2012.11.003.

Su, Yanbing et al. 2017. Global Scientific Collaboration in COPD Research. International Journal of COPD, Vol.12: 215-225. DOI:10.2147/COPD.S124051.

Surjandari, Isti et al. 2015. Big Data Analysis of Indonesian Scholars' Publications: a Research Theme Mapping. International Journal of Technology, Vol.6, No.4: 650-658. DOI:10.14716/ijtech.v6i4.1956.

Sweileh, Waleed M. et al. 2017. Bibliometric Analysis of Worldwide Publications on Multi-, Extensively, and Totally Drug - Resistant Tuberculosis (2006-2015). Multidisciplinary Respiratory Medicine, Vol.11, No.1: 1-16. DOI:10.1186/s40248-016-0081-0.

Sweileh, Waleed M. et al. 2016. A Bibliometric Analysis of Literature on Malaria Vector Resistance: (1996- 2015). Global Health, Vol.12, No.1: 1-13. DOI:10.1186/s12992-016-0214-4.

Sweileh, Waleed M. et al. 2014. Public, Environmental, and Occupational Health Research Activity in Arab Countries: Bibliometric, Citation, and Collaboration Analysis. Archives of Public Health, Vol.73, No.1: 1-12. DOI:10.1186/2049-3258-73-1.

Sweileh, Waleed M. et al. 2016. Bibliometric Profile of The Global Scientific Research on Autism Spectrum Disorders. SpringerPlus, Vol.5, No.1: 1-12. DOI:10.1186/s40064-016-3165-6.

Sweileh, Waleed M. et al. 2016. Drinking and Recreational Water-Related Diseases: a Bibliometric Analysis (1980-2015). Annals of Occupational and Environmental Medicine, Vol.28, No.1: 1-11. DOI:10.1186/s40557-016-0128-x. 
Terekhov, Alexander. I. 2017. Bibliometric Spectroscopy of Russia's Nanotechnology: 2000-2014. Scientometrics, Vol.110, No.3: 1217-1242. DOI:10.1007/s11192-016-2234-5.

United Nations - Statistics Division. 2011. Standard Country or Area Codes for Statistical Use (M49): Geographic Regions. United Nations - Department of Economic and Social Affairs. https://unstats.un.org/unsd/methodology/m49/.

Vanni, Tazio et al. 2014. International Scientific Collaboration in HIV and HPV: a Network Analysis. PLoS ONE, Vol.9, No.3: 1-8. DOI:10.1371/journal.pone.0093376.

Wei, Meiyang et al. 2016. Worldwide Research Productivity in The Field of Spine Surgery: a 10-Year Bibliometric Analysis. European Spine Journal, Vol.25, No.4: 976-982. DOI:10.1007/s00586016-4442-3.

Wiles, Louise et al. 2012. Sixty-Five Years of Physical Therapy: Bibliometric analysis of Research Publications from 1945 through 2010. Physical Therapy, Vol.92, No.2: 493-506. DOI: $10.2522 / \mathrm{ptj} .20110013$

Wilson, Virginia. 2012. Research Methods: Bibliometrics. Evidence Based Library and Information Practice, Vol.7, No.3: 121-123. DOI:10.18438/B82C9K.

Yao, Qiang et al. 2014. Current Performance and Future Trends in Health Care Sciences and Services Research. Scientometrics, Vol.101, No.1: 751-779. DOI:10.1007/s11192-014-1383-7.

Youtie, Jan et al. 2014. Social Dynamics of Research Collaboration: Norms, Practices, and Ethical Issues In Determining Co-Authorship Rights. Scientometrics, Vol.101, No.2: 953-962. DOI:10.1007/s11192-014-1391-7.

$\mathrm{Yu}$, Hao et al. 2016. Assessment on The Research Trend of Low-Carbon Energy Technology Investment: a Bibliometric Analysis. Applied Energy, Vol.184, No. December: 960-970. DOI: 10.1016/j.apenergy.2016.07.129.

Yu, Qi et al. 2013. World Scientific Collaboration in Coronary Heart Disease Research. International Journal of Cardiology, Vol.167, No.3: 631-639. DOI:10.1016/j.ijcard.2012.09.134.

Zhang, Kun et al. 2016. A Bibliometric Analysis of Research on Carbon Tax From 1989 to 2014. Renewable and Sustainable Energy Reviews, Vol.58, No. May: 297-310. DOI:10.1016/j.rser.2015.12.089.

Zhu, Qiaoli et al. 2015. Global Ontology Research Progress: a Bibliometric Analysis. Aslib Journal of Information Management, Vol.67, No.1:27-54. DOI:10.1108/AJIM-05-2014-0061. 